\title{
Flattening of the Phillips Curve: Estimations and consequences for economic policy
}

\author{
Jürgen Kromphardt ${ }^{* * * *}$ and Camille Logeay ${ }^{* * * * *}$
}

\begin{abstract}
We test the hypothesis that the long-term Phillips curve is downward sloping and has become flatter in the last 10 to Is years. Controlling for the most important other factors influencing the inflation rate, we estimate cointegrations and test whether a "break in the Phillips curve can be detected. We restrict our study to Germany, France, Italy, Spain, the UK and the USA. The results vary considerably between the countries, but all exhibit a downward sloping long-run Phillips curve and show the presumed "break«. First we explain the results by changes in the wage or price setting circumstance. Then we critically discuss explanations based on the time-varying NAIRU and put against them explanations based on aggregate demand and hysteresis. In the conclusion, some consequences for economic policy are indicated.
\end{abstract}

JEL classifications: C22, E3I, Eso

Keywords: Phillips curve, NAIRU, unemployment, inflation, hysteresis, cointegration

\section{Introduction}

Since the mid-1990s, the inflation rates of important industrialized countries show no trend in spite of large changes in the rate of unemployment (Figure I, Table I). They remain in a narrow range between I and $3 \%$ when the rate of inflation is measured by the GDP deflator

* Technical University, Berlin.

** University of Applied Sciences HTW Berlin.

*** We thank Stephanie Schneider and two anonymous referees for very helpful comments. The usual disclaimer applies.

Correspondence Address:

Jürgen Kromphardt, Technical University, Dept. of Economics, Str. des 17. Juni 135, D-I0623 Berlin, Germany, e-mail: J.Kromphardt@ww.tu-berlin.de.

Received I7 June 2009, accepted os July 2010

(C) INTERVENTION 8 (I), 2OII, 43-67 
whose advantage is to exclude that part of the inflation which results from the pass-through of higher import prices to the prices of the commodities produced within the country.

Figure I: Annual inflation rates for chosen industrialized countries

(GDP-deflator in \%, quarterly data from 1982 to 2006)

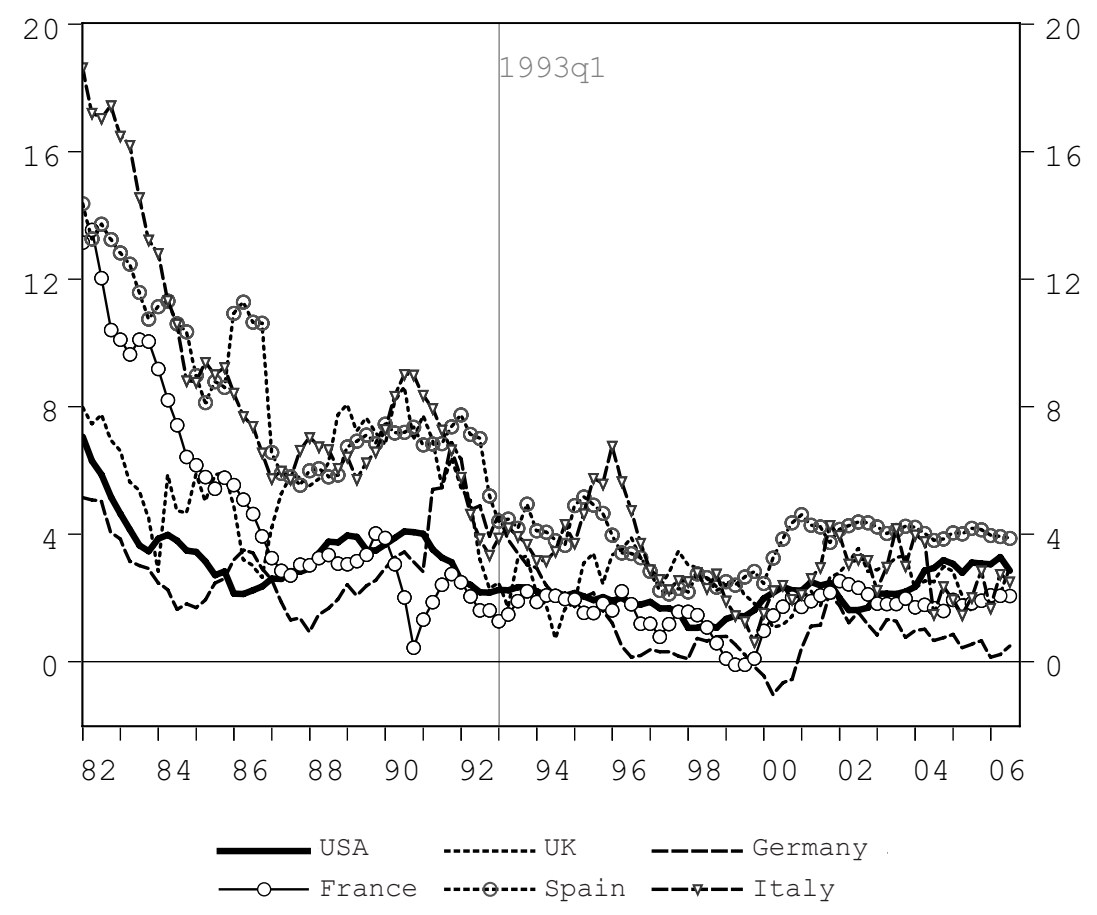

Sources: OECD (EcoWin-Reuters), own calculations

Table I: Declining rates of unemployment since the Ig9os and in \%

\begin{tabular}{c|cccccc}
\hline & USA & UK & Germany & France & Spain & Italy \\
\hline Maximal value & 7.6 & 9.9 & 11.7 & 12.3 & 24.6 & 11.4 \\
(90s) & $1992 q 3$ & $1993 q 1$ & $1997 q 4$ & $1994 q 2$ & $1994 q 1$ & $1998 q 4$ \\
Minimal value & 3.9 & 2.6 & 9.3 & 8.7 & 8.2 & 6.7 \\
(90s and 00s) & $2000 q 4$ & $2005 q 1$ & $2001 q 2$ & $2006 q 3$ & $2006 q 3$ & $2006 q 3$ \\
\hline
\end{tabular}

Note: Germany experienced a break in 2005qI (Hartz-IV). Without it, the minimal value would have occurred at the true end of this sample.

Source: OECD (EcoWin-Reuters), seasonally adjusted quarterly data between 1982 and 2006. 
The relatively stable inflation rates, in spite of huge changes in the rates of unemployment, contrast clearly to the preceding disinflation period from the early I980s to the mid-r990s. During that period, the rates of inflation declined in most OECD countries, accompanied by rising rates of unemployment in conformity with a downward sloping Phillips curve. The actual coexistence of rather stable inflation rates and significantly declining rates of unemployment remains in accordance with such a curve only if its slope has diminished or if the curve has become flat, as Staiger et al. (200I) have already noted for the US during the years I993-I998. In the following we analyze whether the Phillips curves have really flattened, and if so we try to explain this change.

Therefore, we estimate in Section 2 for the six chosen countries Phillips curves relating the inflation rate to the rate of unemployment. We include supply factors and take expectations into account. We then investigate whether a break in the wage- and pricesetting behavior with respect to changing rates of unemployment can be found in the early I990s. In Section 3, we interpret our results. They might be due to a strengthened position of the central banks, whose new vigor in the pursuit of their inflation targets is now taken very seriously by the wage and price setters. Other factors might also work in that direction, especially the globalization of goods and labor markets (see Section 3.I). In Section 3.2, we discuss the alternative concept of a time-varying NAIRU which changes in response to structural factors and has shifted to the left. In Section 3.3 we point to explanations based on aggregate demand and hysteresis. In the last section, we present some implications for macroeconomic policy.

\section{Estimation of long-run Phillips curves (LRPC)}

It would be insufficient to look only at the relation between the two variables »rate of inflation" and "rate of unemployment", and to conclude that the influence of the rate of unemployment on the inflation rate has diminished strongly or even disappeared, because the inflation rate might be influenced by many other factors, and it cannot be ruled out that their effects conceal the continuing influence of the rate of unemployment.

\section{I Wage and price-setting behavior behind the Phillips curve}

When Phillips (1958) presented his original curve showing the negative relation between the rate of change of money wages and the rate of unemployment for the United Kingdom, his explanations of the slope of the resulting curve referred to the behavior of the firms and of the workers on the labor market. The slope of the Phillips curve, when modified by Samuelson and Solow (1960) to a relation between the rate of inflation and unemployment, depends also on the pricing behavior on the markets for commodities. 
A simple model which contains both markets can be written as follows (disregarding productivity growth and supply shock - see Santomero/Seater 1978: 526) ${ }^{\mathrm{I}}$ :

$$
\Delta W_{t}=f\left(u-u^{*}\right)+\alpha_{1} \pi_{t}^{\exp }
$$

where $\Delta W_{t}$ and $\pi_{t}^{\text {exp }}$ are the growth rate of wage and expected price inflation, and $u^{*}$ indicates that rate of unemployment which does not influence the rate of wage (and price) inflation.

$$
\begin{aligned}
& \pi_{t}^{\text {exp }}=\pi_{t-1} \\
& \pi_{t}=\gamma \Delta W_{t}
\end{aligned}
$$

In Santomero and Seater (1978), $\gamma$ equals unity. Thus in their model, the distribution of income between wages and profits remains constant. Inserting (1) and (2) into (3), we get the reduced form of this model:

$$
\pi_{t}=\gamma f\left(u_{t}-u^{*}\right)+\alpha_{1} \pi_{t}^{\exp }
$$

The inflation rate remains constant if $\pi_{t}=\pi_{t-1}$. This is the case when:

$$
\pi_{t}=\frac{\gamma}{1-\alpha_{1} \gamma} f\left(u_{t}-u^{*}\right)
$$

From (5) follows: (a) $\pi_{t}$ remains constant if $u_{t}=u^{*}$, whatever the values for $\gamma$ and $\alpha_{1}$; (b) If and only if $\boldsymbol{\alpha}_{\mathbf{1}} \boldsymbol{\gamma}=\mathbf{1}$, the LRPC is vertical because then the inflation rate is accelerating or decelerating whenever $u_{t} \neq u^{*}$. With $\boldsymbol{\alpha}_{1} \boldsymbol{\gamma}<\mathbf{1}$, the LRPC is downward sloping and a longrun trade-off exists. It should be noted that equations (1) to (3) represent the "expectationaugmented « Phillips curve used by Phelps (1967). The fact that (5) leads to a vertical Phillips curve only if $\boldsymbol{\alpha}_{\mathbf{1}} \boldsymbol{\gamma}=\mathbf{1}$, is not mentioned at all by Phelps.

It would be very informative to estimate a price equation and a wage equation separately (see Flaschel et al. 2007) e.g. to study the relationship between the huge redistribution of income from labor to capital and changes in the wage-price-behavior. But given the difficulties of identification, we restrain our study to the usual method estimating the reduced form (4) and leaving the separate estimation of a wage and price equation to further research. We begin with an overview of the literature concerning such single-equation Phillips curves.

\subsection{Single-equation-Phillips curves in the literature}

There are several competing forms of the (single-equation) Phillips curve as a reduced form of a wage- and price-setting system where wages are influenced by past inflation and unemployment and prices are affected by wage increases: Gordon's triangle model is the most "consensual « for the traditional Phillips curve, i.e. a Phillips curve with adaptive expectations (Gordon 1981, Gordon 1997, Eller/Gordon 2003)²: $\alpha_{p} \pi_{t-p}$. Therefore the sum of the lag-coefficients $\alpha_{1}+\alpha_{2}+\ldots+\alpha_{p}$ can be written more concisely as $\alpha(1)$. 


$$
\pi_{t}=\alpha(L) \pi_{t-1}+\beta(L)\left(u_{t}-u_{t}^{*}\right)+\delta(L) Z_{t}+\varepsilon_{t}
$$

$\pi$ stands for the inflation rate, $u$ for the unemployment rate. The vector $Z$ contains demeaned and de-trended supply-shock variables (oil $\&$ food, exchange rate, price control, tax and minimum-wage effects, ...). The NAIRU $\left(u^{*}\right)$ is usually modeled as a constant or a random walk. Most estimations of such a Phillips curve (Gordon's included) impose the restriction $\alpha(1)=1$. This rules out a long-run non-vertical Phillips curve and is equivalent to estimating the equation in terms of the first difference of inflation $\left(\Delta \pi_{t}\right.$ is then the endogenous variable). This is the most common specification and is used by international organizations like the OECD, the ECB and the European Commission (Richardson et al. 2000, Fabiani/Mestre 200I, McMorrow/Röger 2002). This type of specification cannot answer the question of whether the LRPC is vertical or not because it imposes verticality.

Another specification, also quite consensual, can be taken from Staiger et al. (200I):

$$
\begin{aligned}
\Delta \pi_{t+1}= & c_{0}+\alpha(L) \Delta \pi_{t}-\beta(L)\left(\Delta w_{t}-\Delta \operatorname{prod}_{t-1}^{*}-\pi_{t-1}\right) \\
& +\gamma_{0} X_{t}+\gamma(L) \Delta X_{t}+\delta(L) Z_{t-1}+\varepsilon_{t+1}
\end{aligned}
$$

The most important departure from the first specification consists in the inclusion of the cointegration term $\left(\Delta w_{t}-\Delta \operatorname{prod}_{t-1}^{*}-\pi_{t-1}\right)$ derived from a wage equation not reported here. Because the dependent variable is the first difference of inflation and the unemployment rate is not included in the cointegration term, long-run non-verticality is ruled out in this specification too. Note here that the cointegration is expressed in terms of the differenced variables. Staiger et al. (200I) argue that the levels do not seem to be cointegrated in their data set. $X$ is the unemployment gap or output gap (from a univariate filter method). The $Z$ are, as in Gordon, some de-meaned and de-trended supply-shock variables. The idea of including a cointegration term comes from Blanchard and Katz (I997: 62) and from Sargan (1964). But in their specification, the cointegration term is expressed in levels $\left(w_{t-1}-\operatorname{prod}_{t-1}-p_{t-1}\right)$. They interpret its significance as evidence for labor market theories other than the neo-classical one (efficiency wages, hysteresis with insider/outsider features) where the reservation wage is influenced by productivity.

A »new « strand in the estimation of the Phillips curve, and alternative to the »traditional" Phillips curve presented above, is proposed in New Keynesian theories: $\pi_{t}=\beta \pi_{t+1}^{e}+\alpha X_{t}+\varepsilon_{t} . X_{t}$ is - depending on the authors - the output gap, the unemployment gap or the de-trended real unit labor costs. But the Phillips curve derived by them is far from being satisfactory (even when supply shocks are added, as in Roberts 1995). Although the microfoundations are well derived, the implications of the models are problematic theoretically as well as empirically. Mankiw and Reis (2002) listed the main arguments against such Phillips curves:

I. A credible and long announced disinflation would produce an economic boom against the admitted stylized facts (Ball I994). 
2. The persistency of inflation is not explained through these models. Only the addition of some backward-looking terms reconcile them with the data (Fuhrer/Moore I995).

3. The models cannot reproduce the lagged and spread impact of monetary shocks on the economy, which is also admitted as a stylized fact (Mankiw 200I).

Mankiw (200I: 52) concluded therefore that "although the New Keynesian Phillips curve has many virtues, it also has one striking vice: it is completely at odds with the facts «. ${ }^{3}$ Moreover, quite strong evidence against the hypothesis of rationality can be found in survey data on household and expert inflation expectations; see Nielsen (2003) for Europe, and Grant and Thomas (1999) for the USA. According to Christiano et al. (200I), it seems that the slight modification of the Calvo-price-setting rule leading to the inclusion of a backward-looking term in the Phillips curve becomes a true option in the New Keynesian models (Gali/Gertler 2007, Walsh 2005). But the New Keynesian models are only used for policy simulations to derive the ideal and optimal monetary policy rule. For practical empirical uses, they are not employed because of their empirical inadequacy; the OECD, the IMF and the European Commission indeed still estimate the Phillips curves without forward-looking elements (Turner et al. 200I, IMF 200I, Denis et al. 2006).

All these objections lead us to disregard this kind of specification and choose the »traditional« Phillips curve, but with the possibility of a long-run non-vertical Phillips curve.

\subsection{Our econometric strategy}

\subsection{Our single-equation specifications}

Following the literature, we estimate two types of »traditional« Phillips curves for each country, but in a form that does not rule out long-run non-verticality a priori. Since we are interested in the possible changes of the slope of the Phillips curve, we include as shift parameters of this curve only those variables which are most often used in the literature on Phillips curves. We use two common specifications:

$$
\begin{aligned}
\pi_{t}= & \alpha_{0}+\sum_{i=1}^{8} \alpha_{i} \pi_{t-i}+\beta_{0} u_{t}+\sum_{i=1}^{8} \beta_{i} \Delta u_{t-i}+\delta_{0} \pi_{t-i}^{\text {oil }}+\sum_{i=1}^{8} \delta_{i} \Delta \pi_{t-i}^{\text {oil }} \\
& +\theta_{0} \pi_{t}^{\text {prod }}+\sum_{i=1}^{8} \theta_{i} \Delta \pi_{t-i}^{\text {prod }}+\varepsilon_{t} \\
\Delta \pi_{t}= & \alpha_{0}-\lambda\left[\pi_{t-1}-\beta_{0} u_{t-1}-\theta_{0} \pi_{t-1}^{\text {prod }}-b_{0} \text { trend }\right] \\
& +\sum_{i=1}^{8} \alpha_{i} \Delta \pi_{t-i}+\sum_{i=1}^{8} \beta_{i} \Delta u_{t-i}+\sum_{i=1}^{8} \delta_{i} \Delta \pi_{t-i}^{\text {oil }}+\sum_{i=1}^{8} \theta_{i} \Delta \pi_{t-i}^{\text {prod }}+\varepsilon_{t}
\end{aligned}
$$


These two types differ from each other as follows: In the first specification (equation 8), we estimate the Phillips curve in levels. In contrast to most of the existing literature we do not set $\sum_{i} \alpha_{i}$ to unity and therefore do not rule out the possibility of a downward sloping LRPC. The long-run slope is then equal to $\beta_{0} /\left(1-\sum_{i} \alpha_{i}\right)$. Therefore, the two coefficients $\beta_{0}$ and $\sum_{i} \alpha_{i}$ are of special interest here. If the first is zero, then the long-run Phillips curve is flat. If the second is equal to one, then it is vertical. If the first is negative and the second below one, then the LRPC is downward sloping.

The second specification - albeit not very far from the first in spirit - is closer in its formulation to the standard model because it is expressed as the first difference of the inflation rate. We follow Blanchard and Katz (1997) by including an error correction term. This is superior to the standard specification (equation 6 with $\alpha(1)=1$ ) because it takes into account that the main variables (the inflation rate, the unemployment rate and perhaps the productivity growth) are $\mathrm{I}(1)$ and may be cointegrated ${ }^{4}$ and does not rule out a nonvertical Phillips curve.

Two coefficients are of special interest here. The loading coefficient $(-\lambda)$ measures strictly speaking the adjustment speed of past deviations towards equilibrium (encompassed by the cointegration relation; see Johansen I995). If this coefficient is significantly negative, the cointegration exists (at least between two of the variables $u, \pi, \pi^{\text {prod }}$, trend) and influences the inflation developments (i.e. the inflation rate is not weakly exogenous). The second coefficient of interest is the long-run elasticity of the inflation rate with respect to the unemployment rate $\left(\beta_{0}\right)$. If it is significantly negative (and provided that the loading coefficient is significant), the LRPC is downward sloping. If it is zero, then the Phillips-curve is flat. ${ }^{5}$ If there is no cointegration (the loading is not significantly negative), then only the degree of integration can tell whether the Phillips curve is flat (inflation $\mathrm{I}(0)$ and unemployment rate $\mathrm{I}(1)$ ) or vertical (inflation $\mathrm{I}(1)$ and unemployment rate $\mathrm{I}(0)$ ) or just not existing at all (both being $\mathrm{I}(1))^{6}$. In the latter case, we can interpret this as having short-run Phillips curves without a long-term anchor.

\subsubsection{The data and stationarity tests}

The data used for estimation are all quarterly seasonally adjusted data. Inflation rates are year-on-year-percent changes of the GDP-deflator, the unemployment rates are based on the ILO definitions. For the choice of the exogenous supply-shock variables, we follow the existing literature and take into account the commonly accepted stylized fact that the slowdown of the productivity growth in the Western countries and the oil shocks (1974, I979, I990, I999 and since 2003) have been the major economic supply shocks since I970.

$4 \mathrm{I}(1)$ means integrated of order one and refers to non-stationary series. I( 0$)$ means on the contrary that the series is stationary.

5 The inflation rate net of productivity developments is then $\mathrm{I}(0)$ but the unemployment rate is $\mathrm{I}(1)$, as reported in Table 5, so the Phillips curve is flat.

6 For all countries the inflation rate and the unemployment rate are found to be $I(1)$ for the entire sample as well as for the sub-samples. 
Consequently, we include these shocks in the Phillips curve. The data cover all countries for the period I980qI-2006q3. In some of them, the covered period is longer (USA and UK: 1960qI/q2-2006q3; France and Germany: 1970qI-2006q3). ${ }^{7}$

The inflation rates for all six countries and all periods considered (see Table 5, Annex) are I(1) as well as the unemployment rates. The changes in the price of oil are $\mathrm{I}(0)$. For the growth rate of labor productivity, the figures are not clear-cut. Granger-causality tests were also conducted and confirm the traditional causal direction from unemployment to inflation. However the evidence seems to become weaker from the mid-I99os onward, except for France. Precise definitions, sources and details on the statistical properties are compiled in the Annex (5.I) or can be obtained on request. Tests on the reverse-causality were also performed and show that the evidence for a two-way causality is also fairly weak in the second sub-samples.

We estimate the Phillips curve for each country individually and do not pool the data for two reasons: First, we do not think that all countries have exactly the same breakpoint dates and have in general common coefficients. Indeed, even though the convergence due to the European integration is certainly observed, it is not yet completed. It began for Italy and Spain in 1993, for France perhaps sooner in the 1980s. Germany faced the huge statistical and economic impact of the reunification that did not hit the other European countries with the same strength. Since the UK still has another cyclical development, one cannot really speak of European convergence for the whole sample. Thus, it seemed unadvisable to us to estimate a common Phillips curve for the "old European" countries in a panel estimation. Secondly, data were available in different lengths (UK, Germany and France from at least the I970s; Italy and Spain only from 1980 onwards; USA even from 1960 onwards) rendering a panel estimation unbalanced if one does not wish to forego data.

For the determination of the eventual presence of structural breaks, we follow the usual literature (Hansen 200I) and perform F-tests like the Chow- or Quandt-tests, RSS-tests, CUSUM and CUSUM ${ }^{2}$ and we look at the recursive and rolling estimates of coefficients of interest (for a description see Annex 5.4).

\subsection{Results}

In a first table (Table 2), the results from the stability tests are summarized. For each country a breakpoint can be found either in the first half of the 1990 or in the second half of the I990s (Italy and Spain). The stability tests confirm the existence of the expected break in the Phillips curve in all six countries during the I990s. Only in the UK the latest break is found in 1987. The late appearance of the break in Italy and Spain may be related to the strong efforts of these countries to fulfill the Maastricht criteria for entrance in the EMU.

7 The statistical break due to the German Reunification is solved as follows: Fictive whole German levels are calculated backwards from the first available data for reunified Germany (I99IqI) with the help of the original West-German growth rates. 


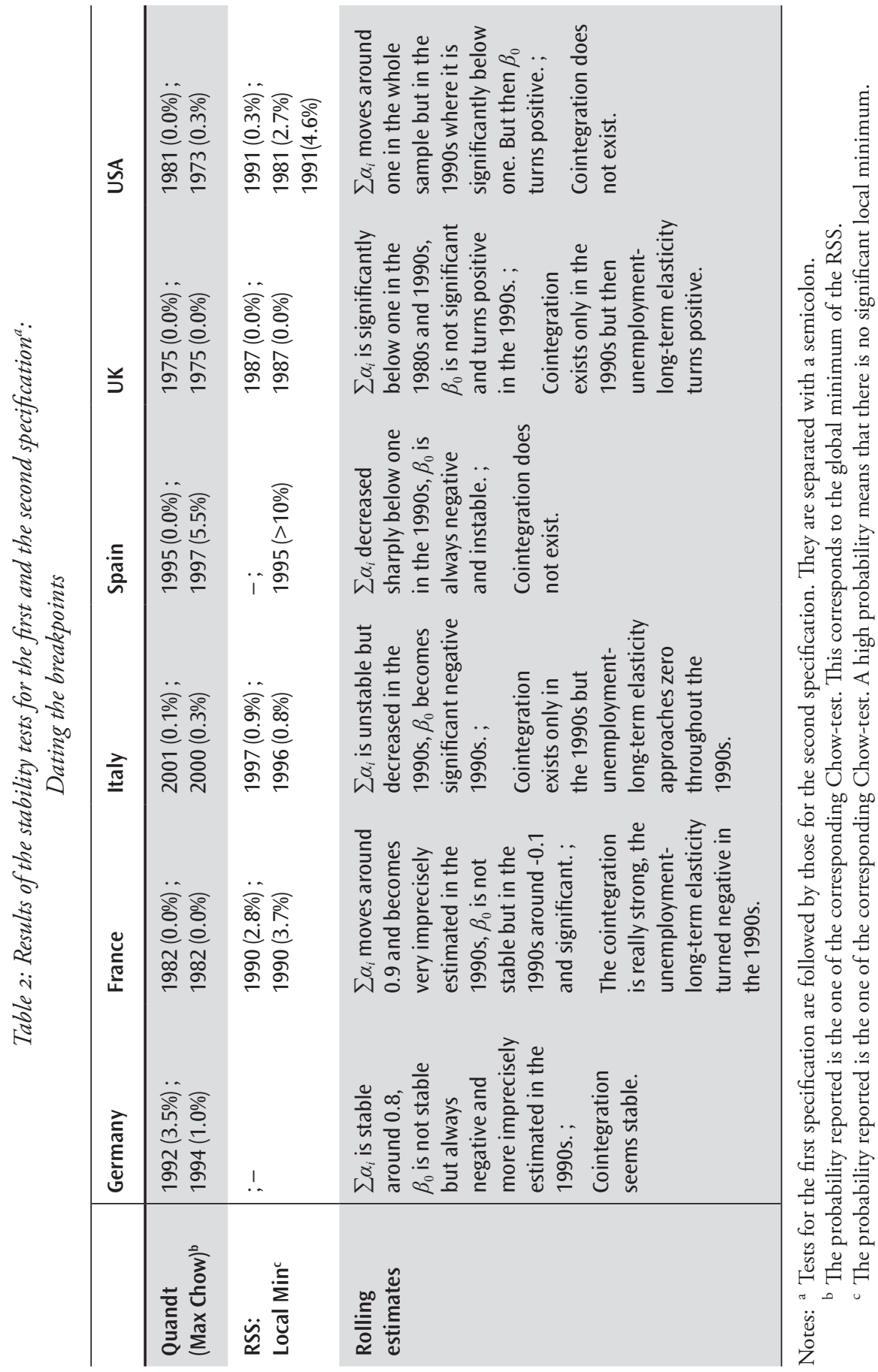


Table 3: Results

\begin{tabular}{|c|c|c|c|c|c|}
\hline \multirow{2}{*}{$\begin{array}{l}\text { Country } \\
\text { and } \\
\text { time period }\end{array}$} & \multicolumn{3}{|c|}{ Equation 8} & \multicolumn{2}{|c|}{ Equation 9} \\
\hline & $\begin{array}{c}\mathrm{H} 0:=1 \\
\sum_{i} \alpha_{i}\end{array}$ & $\begin{array}{c}\mathrm{H} 0:=0 \\
\beta_{0}\end{array}$ & $\begin{array}{c}\text { HO: }=0 \\
\text { I-t e. }\end{array}$ & $\begin{array}{c}\mathrm{H} 0:=0 \\
\lambda\end{array}$ & $\begin{array}{c}\mathrm{H} 0:=0 \\
\beta_{0}\end{array}$ \\
\hline \multicolumn{6}{|l|}{ Germany } \\
\hline \multirow[t]{2}{*}{ 1971q1-1989q4 } & $0.822^{* * *}$ & $-0.086^{* * *}$ & $-0.487^{* * *}$ & -0.093 & -0.506 \\
\hline & $(0.044)$ & $(0.024)$ & $(0.071)$ & $(0.046)$ & $(0.434)$ \\
\hline \multirow[t]{2}{*}{$1994 q 1-2006 q 3$} & $0.837^{* * *}$ & $-0.074^{*}$ & $-0.451^{* *}$ & $-0.182^{* * *}$ & 0.117 \\
\hline & $(0.038)$ & $(0.038)$ & $(0.224)$ & $(0.032)$ & $(0.211)$ \\
\hline Breakpoints: & \multicolumn{3}{|c|}{ 1992-93 } & \multicolumn{2}{|c|}{ 1993-94 } \\
\hline \multicolumn{6}{|l|}{ France } \\
\hline \multirow[t]{2}{*}{$1971 q 1-1989 q 4$} & $0.921^{* * *}$ & $-0.118^{* * *}$ & $-1.498^{* * *}$ & $-0.112^{* *}$ & $-2.963^{* * *}$ \\
\hline & $(0.022)$ & $(0.029)$ & $(0.423)$ & $(0.026)$ & $(1.173)$ \\
\hline \multirow{2}{*}{$1991 q 1-2006 q 3$} & $0.803^{* * *}$ & $-0.100^{* * * *}$ & $-0.508^{* * *}$ & $-0.218^{* *}$ & $-0.628^{* * *}$ \\
\hline & $(0.054)$ & $(0.024)$ & $(0.167)$ & $(0.049)$ & $(0.160)$ \\
\hline Breakpoints: & \multicolumn{3}{|c|}{$1979-83+1990$} & \multicolumn{2}{|c|}{$1982-83+1990$} \\
\hline \multicolumn{6}{|l|}{ Italy } \\
\hline \multirow[t]{2}{*}{$1981 q 1-1994 q 4$} & $0.838^{* * *}$ & $-0.172^{* *}$ & $-1.059 * * *$ & $-0.166^{* * *}$ & $-6.110^{* * *}$ \\
\hline & $(0.016)$ & $(0.075)$ & $(0.375)$ & $(0.024)$ & $(0.734)$ \\
\hline \multirow[t]{2}{*}{$1996 q 1-2006 q 3$} & $0.751^{* * *}$ & -0.004 & -0.014 & $-4.338^{* * *}$ & $-2.523^{* * *}$ \\
\hline & $(0.065)$ & $(0.043)$ & $(0.173)$ & $(0.224)$ & $(0.030)$ \\
\hline Breakpoints: & \multicolumn{3}{|c|}{$1995-97+2001-03$} & \multicolumn{2}{|c|}{$1995-96+2000$} \\
\hline \multicolumn{6}{|l|}{ Spain } \\
\hline \multirow[t]{2}{*}{ 1981q1-1994q4 } & $0.845^{* * *}$ & $-0.221^{* * *}$ & $-1.427^{* * *}$ & $-0.321 * * *$ & 0.071 \\
\hline & $(0.027)$ & $(0.035)$ & $(0.196)$ & $(0.053)$ & $(0.085)$ \\
\hline \multirow[t]{2}{*}{$1996 q 1-2006 q 3$} & $0.729^{* * *}$ & $-0.033^{* * *}$ & $-0.120^{* * *}$ & $-0.344^{* * *}$ & $-0.322^{* * *}$ \\
\hline & $(0.075)$ & $(0.007)$ & $(0.028)$ & $(0.049)$ & $(0.070)$ \\
\hline Breakpoints: & \multicolumn{3}{|c|}{1995} & \multicolumn{2}{|c|}{1997} \\
\hline \multicolumn{6}{|l|}{ UK } \\
\hline \multirow[t]{2}{*}{$1961 q 2-1973 q 4$} & 1.021 & $0.470^{* *}$ & -22.693 & $>0$ & - \\
\hline & $(0.045)$ & $(0.197)$ & (82.284) & & \\
\hline $1976 q 1-1987 q 4$ & $0.784^{* * *}$ & $-0.220^{* *}$ & $-1.019 * * * *$ & -0.137 & $-0.594^{* * *}$ \\
\hline & $(0.051)$ & $(0.088)$ & $(0.242)$ & $(0.065)$ & $(0.262)$ \\
\hline $1990 q 1-2006 q 3$ & $0.758^{* * * *}$ & $0.080^{* * *}$ & $0.331^{* * *}$ & $-0.327^{* * *}$ & -0.216 \\
\hline & $(0.048)$ & $(0.037)$ & $(0.123)$ & $(0.067)$ & $(0.200)$ \\
\hline Breakpoints: & & nid 1970's + 1s & & $\operatorname{mid} 1$ & 1987 \\
\hline USA & & & & & \\
\hline $1960 q 1-1974 q 4$ & $1.157^{* * *}$ & $0.161^{* * *}$ & $-1.022^{* * *}$ & -0.041 & 2.42 \\
\hline & $(0.018)$ & $(0.028)$ & $(0.188)$ & $(0.048)$ & (3.288) \\
\hline $1977 q 1-1989 q 4$ & $1.072^{* * *}$ & $-0.329 * * * *$ & $4.579 * * *$ & -0.101 & $-2.160^{* * * *}$ \\
\hline & $(0.020)$ & $(0.058)$ & $(0.835)$ & $(0.023)$ & $(0.492)$ \\
\hline $1991 q 1-2006 q 3$ & $0.857^{* * *}$ & $0.054^{*}$ & $0.376^{* *}$ & -0.037 & -0.113 \\
\hline & $(0.042)$ & $(0.031)$ & $(0.164)$ & $(0.039)$ & $(0.815)$ \\
\hline Breakpoints: & & $1981+1990-\mathrm{c}$ & & $1973+$ & -1991 \\
\hline
\end{tabular}

Notes: 1-t e: Long-term elasticity $\left(\beta_{0} /\left(1-\sum_{i} \alpha_{i}\right)\right)$. ${ }^{*},{ }^{* *},{ }^{* * *}$ Reject the null at the Io\%, $5 \%$, I $\%$ level. No star: Not significant (do not reject the null). In equation 8 the tests are based on Wald-statistics and their asymptotic distribution $\left(\chi^{2}(1)\right)$. The reported s.e. are obtained from the Delta method. In equation 9 the cointegration test ( $\mathrm{H} 0: \lambda=0)$ is based on Banerjee et al. (I998). The distribution for the last test is non-standard and unknown, the normal distribution is used here and thus subject to caution. Standard errors are in parenthesis. 
On this evidence the two specifications are re-estimated for the two sub-samples - before and after the last detected breakpoint. The results of this second step are presented in Table 3 . We do not indicate coefficients for the whole sample, because in the presence of structural breaks, they are biased and unreliable.

Compared to the bivariate static Phillips curves, which are flat in 5 of our 6 chosen countries during the last ten to thirteen years, the results of our econometric analysis (Table 3) are more differentiated. We start with the aspects of our results that correspond to a Keynesian interpretation:

I. The results summarized in Table 3 show that at least since the beginning of the disinflation period, there does not exist any vertical Phillips curve. During the period examined before the breaks, the results already indicate, for four of the six countries, a downward sloping LRPC. After the breaks, the relevant parameter is significantly below unity for all countries and the LRPC are downward sloping.

2. In Germany, France, Italy and Spain, equation (8) indicates a flattening of the estimated Phillips curve; in Italy it has even been flat since 1996, for Germany the evidence for a flattening may be weaker. The (-0.5)-elasticities for Germany correspond to those calculated by Schreiber and Wolters (2005). The presence of a thoroughly downward sloping curve is also found in Franz (2005). The results of equation (9) confirm these results for Germany, France and Spain. For Spain where $\beta_{0}$ was not significantly different from zero (i.e. a flat Phillips curve) in the first period, the long-run Phillips curve becomes downward sloping.

The weaker results are:

3. For the UK we obtain a flattening of the curve between the disinflation period and the latest period. But since 1990 the Phillips curve is sloping slightly upward (the equation (9) points rather to a flat Phillips curve) and we are not yet able to explain these results. Haldane and Quah (1999) find that the UK Phillips curve re-emerged after I980 as horizontal and explain this with the evolving beliefs and strategies of monetary policy there.

4. For the USA the results indicate (if any) a positively sloping long-run Phillips curve. This is rather difficult to explain but confirms the findings of other empirical studies (e.g. Beyer/Farmer 2002, Ireland 1999). For the period 1962 to 1995 Setterfield and Leblond (2003: 370-37I) could neither refute the hypothesis of a vertical LRPC nor the existence of a downward sloping LRPC.

5. Equation (9), which includes an error correction term, does not yield clear results since, especially in the countries without the expected results, too often no cointegration is found.

Our results contrast sharply to the claim that the LRPC is vertical. They are confirmed by other empirical studies: For Germany, Franz (2005: I46) reaches the conclusion that for the 
period 1972 to $2002 »$ the coefficient associated with the sum of lagged inflation rates is well below unity in all estimated Phillips curves [...]. It means that strictly speaking there exists no such thing as a vertical Phillips curve".

For Europe, the existence of the downward sloping LRPC is supported by Karanassou et al. (2003). They use data for the years 1970 to 1998 and reach the conclusion that the EU faces a long-run inflation-unemployment trade-off.

The IMF (2006: chap. 3) in trying to determine the weight to be attributed to the different determining factors finds that the persistency of inflation diminished from 1983 to 2004 for eight advanced economies (between them five of our six countries). The coefficients controlling the slope of the long-run Phillips curve have decreased over the sample.

\section{Explanation of our results}

\section{I Flattening of the Phillips curve}

The slope of the LRPC depends (see equations I and 2) first on the power of wage setters and their willingness to raise their nominal wages in compensation for an (expected) increase of the inflation rate and to raise them farther in times of high employment $\left(u<u^{*}\right)$, and secondly on the power and willingness of the firms to pass-through higher wages into the prices of their products.

Therefore, the flattening of the Phillips curve in some of our countries has to be explained by forced or voluntary changes of behavior. In the literature, a certain number of reasons for such changes are discussed:

a) Taylor (2000: 1389), argues that "the decline in pass-through or pricing power is due to the low inflation environment that has recently been achieved in many countries".

b) The dating of breaks in the relation between inflation and unemployment suggests that the behavior of the wage and price setters changed because of stronger acceptance of the goals and the credibility of the policy of the central banks.

c) A factor which might have weakened the position of the price- and wage-setters in all countries is the process of globalization; a higher economic interdependence introduces more competition and lowers market power in both markets. Especially in developed economies the threat of job off-shoring and labor immigration tends to moderate wages (ECB 2006: Box 6, ECB 2007: Box 13, Papademos 2007).

These different factors have been the object of many research studies in recent years (see e.g. Iakova 2007). Especially the credibility of monetary policy and the degree of openness are found to have contributed to the changes in price- and wage-setting behaviors. The IMF (2006: chap. 3) quantifies the improved monetary policy and enhanced credibility to have contributed to half of the declined sensitivity of prices to the domestic product, with increased openness of the economies accounting for the rest.

d) In some countries important institutional changes have occurred on the labor market: In the United-Kingdom the reforms of the Thatcher area resulted in a drastic weakening of 
the power and influence of the trade unions and probably contributed to the break in the year I986 in the behavior of the wage and price setters (Pissarides 2003). In Spain labor market reforms were introduced in 1994 and 1997 to improve the collective bargaining process. In Italy the "scala mobile « which linked wage rates to the inflation rate was abandoned in 1992 (see OECD 1993: 19). In France a policy of subsidies for social security contribution at the minimum wage level started in 1993 , together with a relatively moderate development of the minimum wage in the I990s, produced a further incentive to the wage moderation that began with the disinflation policy (Logeay/Schreiber 2006).

Presumably, the efforts of Spain and Italy to enter the European Monetary System and the European Currency Union (ECU) were still more important for the achievement of stable and low inflation rates in spite of falling rates of unemployment. The factors discussed in this section may even result in a flat LRPC in the future. This change might be realized more easily by coordinated wage bargaining (Hein 2006, Hein/Stockhammer 2009).

In sum, plausible arguments exist to explain the flattening of the Phillips curve observed in some of our six countries. However, it is difficult - and not the aim of our paper - to quantify their importance.

\subsection{An opposite approach: Time-varying NAIRU's}

Contrary to the interpretation of our results in the former section, the literature is dominated by the competing view that the LRPC is vertical but that this curve and correspondingly the NAIRU have shifted to the left since the mid-I990s, above all due to structural changes. In terms of equation (4), this means that $u^{*}$ is not a constant but it is time-varying. Stockhammer (2004: 4) highlighted that this hypothesis (named by him the `NAIRU hypothesis) involves the claim that "changes in the NAIRU have caused changes in actual unemployment. Thus changes in the NAIRU are understood to be relatively autonomous with respect to changes in actual unemployment and the NAIRU serves as a strong attractor for actual unemployment". In the following we discuss the weak points of this alternative explanation.

Since the end of the I990s, it is an accepted view that the NAIRU must be timevarying. It is also generally accepted that it is difficult to measure the time-varying NAIRU. And indeed, all international institutions (Turner et al. 200I, IMF 200I, Denis et al. 2006) estimate a time-varying NAIRU that is actually not more than the trend of the observed unemployment rate. The revisions from year to year are substantial (the gaps even change sign). Due to the end-point problem common to the Hodrick-Prescott-Filter and the Kalman-Filter techniques used by these institutions, the uncertainty about these estimates is indeed great. We agree with Laubach (200I: 220), who raises doubts about what these estimates measure:

"The finding that information from unemployment data greatly improves the precision of the NAIRU estimates raises the question whether these estimates are in fact linked to inflation, or just smoothed unemployment series." 
The adherents to this explanation claim that only structural changes - mainly on the labor market - shift the NAIRU to the left (or to the right, if they go into the wrong direction). On the contrary, the actual unemployment - since it oscillates around the NAIRU - does not contribute to the changes in the value of the NAIRU. The most prominent examples of this approach are the OECD-Jobs-Study (OECD 1994) and Katz and Krueger (1999). Consequently, in the "Jobs Strategy" derived from the OECD-Jobs-Study, the nine components of this strategy mainly concern changes in the labor market and in social institutions supplemented by enhanced product market competition, a better framework for the creation and diffusion of technological knowledge. Only the last component advises an appropriate macroeconomic policy; but this has - except for the short-term business cycle policy - little in common with a macroeconomic policy in the Keynesian sense aiming at a durable expansion of the demand for commodities to create new jobs. Instead it focuses on medium-term fiscal consolidation and price stability.

Other studies choose a slightly different way to prove the overwhelming importance of structural changes for the evolution of the unemployment rate in the OECD countries. The OECD staff provides a recent example in its »Employment Outlook 2006«. There, the changes of the unemployment rate from 1982 to 2003 are explained by five structural factors and by the output-gap which measures are the cyclical deviations from the trend. The OECD staff obtains the result that the output-gap contributes much less to the changes in unemployment than the structural factors (OECD 2006, Fig. 7.3: 214; Bassanini/Duval 2006). However since only the output-gap and not the output itself is included as an explanatory variable, the influence of the growth performance of a country is ignored. The importance of this omission can be seen when looking at the most extreme case, Ireland, where the unemployment rate diminished by almost 8 percentage-points. In the OECDcalculations the influence of the well-known extraordinary growth performance in Ireland ${ }^{8}$ on the rate of unemployment is not taken into account.

In a similar way, Staiger et al. (200I: 5), observing that the statistical Phillips curve for the USA remains flat from 1993 to 1998 , try to show that »the Phillips curve has shifted in, not flattened out «. They also exclude the growth performance by substituting the unemployment rate with the unemployment gap defined as the "deviation of the actual rate of unemployment from an (unexplainable) univariate (stochastic) trend rate of unemployment«. But, if the trend rate is well measured, any flattening of the Phillips curve tends to disappear. Moreover, the authors have to admit that "our regressions using the state data fail to isolate any economic or demographic determinants of the trend unemployment rate (Staiger et al., 200I: 6). Therefore, their conclusion of a shifted rather than flattened Phillips curve must be doubted. The authors themselves mention that labor market factors and policies "must be the source of the changes in the NAIRU. Curiously, however, our results do not point in this direction«. Indeed, this approach faces the problem that the regulations considered often became less rigid, i.e. changed in the wrong direction. At least, the mavailable measures

8 Ireland did grow by $6.8 \%$ p.a. between I99I and 2007, against $2.0 \%$ p.a. for the EU-I5. Even with correcting for the different population developments, the Irish performance remained very impressive. 
of labor market institutions do not show the sharp deterioration [...] implied by the story" (Blanchard 2007: 4I7).

In addition to the structural changes on the labor market that influence the efficiency of matching workers and jobs as well as the anxiety about job security, Katz and Krueger (I999) add two further new structural factors to explain the fall in the NAIRU: a) favorable demographic trends and b) an increase in the prison population. The authors conclude:

"The evidence suggests to us that demographic shifts and the rise of labor market intermediaries [...] are the main labor market changes that have contributed to the decline in unemployment."(Katz/Krueger, 1999: 55)

The demographic factor seems to explain one half of the fall in the rate of unemployment; the effect of changes in labor market efficiency is less certain, the increase in incarcerated population has a much smaller effect (see their Table 13: 79). The importance of demographic shifts were also discussed by other authors (Stiglitz 1997, Ball/Mankiw 2002, Wall/Zoëga 2004), ${ }^{9}$ whereas Staiger et al. (1997) use the unemployment rate for young men only and Ball and Mankiw (2002) a "Perry-weighted « unemployment rate. ${ }^{\text {I }}$

Because of the importance attributed to demographic changes in the USA we analyze this factor with more recent data for the European countries and with Perry-weighted unemployment rates. ${ }^{\text {II }}$ The changes for these European countries are quite small. The maximal positive effect (increase of the NAIRU) lies between o and 0.6 percentage-points at the beginning of the sample (I984-9I). The maximal negative effect (decrease of the NAIRU) is higher for all countries, lies between -0.5 and $-\mathrm{I} .5$ percentage-points and is achieved at the end of the sample (2005-06, for France also 1997). The demographic effects on the NAIRU are relatively modest if one compares these ranges with the overall maximal actual fall in their unemployment rates (between 5.5 and 15.7 percentage-points). For the countries

9 Stiglitz (1997) measures this effect for the USA with $\mathrm{I} / 3$ of the decline of the NAIRU, the latest being accounted with I.5 percentage-points between the early I980s and 1995. To the same modest effect come Ball and Mankiw (2002) for the period 1960-200o for the USA. Wall and Zoëga (2004: 30) measure the effect of demographic changes on the US NAIRU between 1982 and 2000 with 0.7 percentage points in 2000 .

IO The »Perry-weighted «-unemployment rate divides the labor force in subgroups (gender/age) and maintains their respective shares fictitiously constant over the period considered, whereas their unemployment rates are the original ones. The difference between this fictive unemployment rate and the actual one gives the potential effects of the gender/age-shift effects on the unemployment rate.

II We decomposed the overall unemployment rate of each country in the weighted sum of unemployment rates of subgroups from the Labor Force Survey of Eurostat (Mikrozensus directly for Germany). The subgroups are defined along five age groups (Io for Germany) up to is years and along the two genders. We have therefore Io subgroups (20 for Germany) from 1982/86 onward (I975 for Germany). The Perryweighted unemployment rate is obtained in keeping the weighting scheme - i.e. the share of each subgroup in the overall labor force - constant. The base year is the first year of available data. The maximal deviations (positive and negative) from the Perry-weighted unemployment rate and the actual unemployment rate are reported in the text. 
studied, demography cannot contribute to explaining the rise and the decline of the NAIRU in the period considered. ${ }^{\mathrm{I}}$

\subsection{Explanation of changes in unemployment via aggregate demand and hysteresis}

Obviously, it is very difficult to explain the large changes in unemployment observed during the period considered via the NAIRU hypothesis. Therefore, we point to explanations for these changes which are consistent with downward sloping LRPC's and where the NAIRU has no explanatory power but adjusts itself to the actual employment (thus $u^{*}$ depends on $u_{t}$ in equation 4 ). The most important factor of this adjustment is given by hysteresis in the labor market.

Hysteresis, introduced by Blanchard and Summers (I986), means: In times of rising unemployment, the workers who lost their job may - after a certain period of unemployment - loose their motivation to search for a new job, they may lose their skills and they do not get acquainted with new techniques demanding new skills. On the other side of the market potential employers often believe that "the long-term unemployed are unmotivated and lacking in relevant skill and work habits" (Layard et al. I99I: 258).

Ball (I997: I68) underlines that hysteresis shifts the NAIRU in the same direction as the actual unemployment rate:

"In particular, I focus on the decade of the r980s and argue that the main cause of rising unemployment was the tight monetary policy that most OECD countries pursued to reduce inflation. [...] My argument is inconsistent with traditional natural-rate models. My findings fit easily, however, with "hysteresis « theories (Blanchard/Summers 1986). In these theories, a disinflation causes a cyclical rise in unemployment, which in turn causes a rise in the NAIRU ${ }$.

Whilst the working of hysteresis is easy to accept in the case of rising unemployment, it is less convincing in times when the unemployment changes in the other direction. For Stiglitz (I997: 8),

"research has not conclusively shown that hysteresis is one of the forces that has lowered the NAIRU in the American economy. But if it does, then high unemployment is even worse than we thought, because it raises the NAIRU, and lower unemployment is better than we thought because it reduces the NAIRU«.

What remains is to analyze the factors which determine actual unemployment. Ball (I999: I89) presents results for six of the G7-countries which experienced recessions beginning in the early I980s: "Over the last twenty years the behavior of demand counts for much of the differences across countries in the evolution of unemployment." Based on empirics of four European countries which experienced a sharp fall in unemployment, Ball shows that 
hysteresis also worked in a positive direction and can explain the decline of the NAIRU because the newly employed persons regain their qualities via learning by doing.

The importance of the demand side is also shown by Stockhammer (2004) who tests empirically whether changes in demand or structural factors have been the key causes of unemployment from the mid I960s to the mid I990s in the countries we analyzed in Section 2 (Spain excepted). As the demand variable he uses the accumulation of the business capital stock. Stockhammer summarizes the result of his regressions as follows:

»Overall accumulation does seem to do a better job in explaining unemployment than institutional variables" (Stockhammer 2004: 17), "capital accumulation being statistically significant in all countries and robust to changes in the specification." (Stockhammer 2004: I)

A time-varying NAIRU which reacts to changes in the actual unemployment rate does not contradict a downward sloping (and in some countries flattening) Phillips curve: Both predict that a permanent expansion of demand (which leads to an unemployment rate beneath the actual NAIRU) does not lead to accelerating inflation since the NAIRU follows the actual unemployment. Instead the result will be a (presumably somewhat higher) stable inflation rate. The LRPC indicates how high the stable inflation rate will be, the NAIRU only tells us that it will be stable.

\section{Consequences for economic policy}

Our econometric analysis, taking account of the most important other factors that influence the inflation rate (productivity growth and oil price hikes), confirms, in accordance with other studies, that no vertical Phillips curve has ever existed after the beginning of the disinflation period in all countries and even before in the continental European countries. Furthermore, a »break» in the Phillips curves is confirmed for all countries during the early or middle I990s (only in the UK it already occurred in 1986). After the »break«, the estimated Phillips curves have been flatter in all European countries (except perhaps Germany). In Italy it is completely flat since 1996; the unemployment rate completely lost its influence on the inflation rate.

A consequence of these results for policy is that especially the ECB should be courageous to pursue an expansionary policy stance when the unemployment begins to decline and unfounded fears of accelerating inflation appear.

Since aggregate demand is an important but not the only factor influencing the rate of unemployment, macroeconomic policy should follow the "two-handed approach" recommended by Andrés et al. (1995), Bean (1997), Modigliani et al. (I998), Solow (2000), and others. This approach demands that the political institutions take measures on the supply side and the demand side to foster employment. This call should especially be heard by the policy makers in the Euro area where both the monetary authority (the ECB) and the fiscal authorities are often inclined to disregard the necessity and usefulness of active macroeconomic policy. 


\section{Annex \\ 5.I Description of the data}

The data are quarterly data. The abbreviations are as follows:

Table 4: Description of the data

\begin{tabular}{l|l}
\hline Variable Name & Description \\
\hline PGDP & $\begin{array}{l}\text { Deflator of the Gross Domestic Product. Eurostat (national Account statistics); } \\
\text { seasonally adjusted quarterly series. The inflation rate from this series is built } \\
\text { as the year-on-year-growth rate in \%. } \\
\text { Unemployment Rate in \%. OECD, seasonally adjusted quarterly series. } \\
\text { UR }\end{array}$ \\
\hline OProd & $\begin{array}{l}\text { Labor productivity (real GDP per person in employment), index (2000=100), } \\
\text { seasonally adjusted. Destatis, Eurostat, OECD. } \\
\text { Oil Price in national currency (average of crude). IMF-IFS; 1957q1 2006q4. }\end{array}$ \\
\hline
\end{tabular}

\subsection{Unit root tests}

The unit root tests were performed on the levels and first difference of the data. The test used is the Augmented Dickey-Fuller (ADF) test. A constant was always included and a variant with a trend was performed also. All tests are performed routinely by EViews. The results are summarized in the table below.

ADF-tests on the subsamples (as reported in Table 3) for the unemployment rate and the inflation rate do not yield fundamentally different results: both variables are also in the sub-samples considered to be I(1). Only in Spain (I980-1994) and UK (I976-1987 and 1990-2006) the ADF-tests seemed to suggest that the unemployment rate would be $\mathrm{I}(2)$ what is not very sensible and probably due to the small size of the sample. Details and results for the subsamples can be obtained from the authors on request. 
Table 5: ADF-tests (with AIC-Lag selection)

\begin{tabular}{|c|c|c|c|c|c|}
\hline Var. name & Country & level & diff. & Sample & Remarks \\
\hline \multirow[t]{6}{*}{$\pi^{P G D P}$} & DEU & $* * *$ & $* *$ & 1973/74-2006 & With SC-lag selection: $* * * /-$ \\
\hline & FRA & $* * *$ & * & $1973 / 74-2006$ & \\
\hline & ITA & * & - & $1984-2006$ & Trend-stationary \\
\hline & ESP & $* * *$ & - & $1983 / 84-2006$ & Trend is necessary \\
\hline & UK & $* * *$ & - & $1959-2006$ & \\
\hline & USA & $* * *$ & - & $1951-2006$ & \\
\hline \multirow[t]{6}{*}{ UR } & DEU & $* * *$ & - & $1969-2006$ & \\
\hline & FRA & $* * *$ & - & 1968-2006 & \\
\hline & ITA & $* * *$ & - & $1961-2006$ & \\
\hline & ESP & $* * *$ & $* * *$ & $1975-2006$ & \\
\hline & UK & $* * *$ & - & $1960-2006$ & \\
\hline & USA & $* * *$ & - & $1962-2006$ & \\
\hline \multirow[t]{6}{*}{$\pi^{\text {LaborProd }}$} & DEU & $* * *$ & - & $1974-2006$ & \\
\hline & FRA & * to - & - & $1974-2006$ & \\
\hline & ITA & * & - & $1973 / 74-2006$ & \\
\hline & ESP & $* *$ & - & $1974-2006$ & \\
\hline & UK & - & - & 1963/64-2006 & \\
\hline & USA & $* *$ to - & - & $1952-2006$ & \\
\hline \multirow[t]{6}{*}{ OIL } & DEU & $* * *$ & - & $1958-2006$ & \\
\hline & FRA & $* * *$ & - & $1958-2006$ & \\
\hline & ITA & $* * *$ & - & $1958-2006$ & \\
\hline & ESP & $* * *$ & - & $1958-2006$ & \\
\hline & UK & $* * *$ & - & $1958-2006$ & \\
\hline & USA & $* * *$ & - & $1958-2006$ & \\
\hline
\end{tabular}

$* / * * / * * * \quad$ Do not reject $\mathrm{H} 0$ (unit root) at I\%, 5\%, IO\%

\subsection{Granger-Causality tests}

Granger-causality tests within bivariate VARs (with a constant, a deterministic trend and, if necessary, impulse dummies for outliers in the inflation equation and different lag-lengths) were conducted between all variables and the inflation rate. Especially interesting are the results for the unemployment rate. The tests were conducted for all possible samples from I960qI-2006q4 to 2002qI-2006q4. The results for chosen sample sizes are summarized in Table 6. 


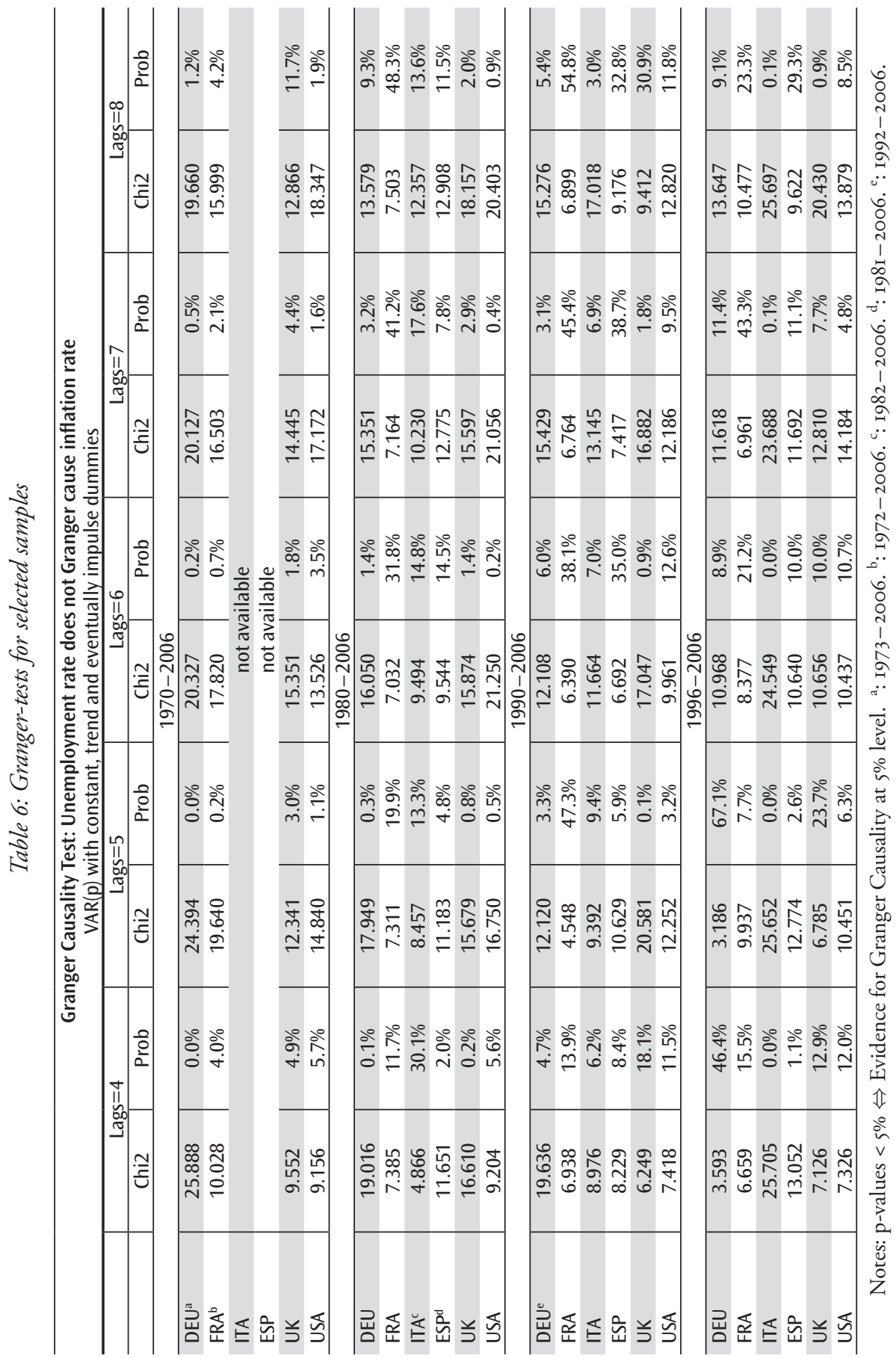




\subsection{Description of the stability tests in use}

The tests used are constructed as follows:

Chow- or Quandt-test: The sample is parted in two subsamples whereas the parting time date or breakpoint goes from a time point $t_{1}$ to another $t_{2}$. Following Hansen (1997), these two time points are chosen as to imply a $15 \%$ symmetric trimming. For $t$ going from $t_{1}$ to $t_{2}$, a Chow-test is performed and the respective Wald-statistics and $F$-statistics are stored. As our models are linear, they will not differ except for a constant factor term. Three Quandt-statistics are proposed by Andrews (1993) and Andrews and Ploberger (1994): the maximal $F$-statistic, the exponential average of all $F$-statistics and the simple average of the $F$-statistics. For all of them, a p-value can be derived from Hansen (1997). We look however only at the first one. The data where the statistics are maximal indicate the possible breakpoint(s). These statistics are now computed in version 6 of EViews and are used here. This test assumes homoscedastic errors in the whole sample. This is why we also perform the next test.

RSS-Test: The same splitting method is used as above. For both subsamples a regression is performed and the estimated residual sum of squares (RSS) is stored and added together (Hansen 200I: I2I-I22). A plot of the overall RSS give insight for possible break(s) (local and global minima). Here, the assumption of homoscedasticity is released and provide an alternative if the homoscedasticity tests do fail.

CUSUM and CUSUM²: Using subsets of the sample data becoming larger and larger, the equation is estimated at each step and the estimated coefficients are used to perform a onestep-forecast. Both tests are based on the obtained series of one-step-ahead and standardized forecast errors, precisely on their cumulative sum. They are provided in any statistical packages as standards. Here, the plots performed by EViews are used and the statistics are computed after Brown et al. (1975). When the statistics are outside the confidence bounds, there is an indication for instability. The CUSUM tests for overall parameter stability whereas the CUSUM $^{2}$ for variance stability.

Recursive coefficient estimates: They are provided by EViews also. The equation is estimated repeatedly using ever larger subsets of the sample data. For each estimation the estimate of the coefficient(s) of interest is stored and pictured within its $95 \%$ confidence interval. According to the user manual of EViews: "If the coefficient displays significant variation as more data is added to the estimating equation, it is a strong indication of instability."

Rolling coefficient estimates: The equations are estimated over a window of to years or 40 observations starting from the earliest possible to the latest. All coefficients with their respective $\mathrm{p}$-values are stored and the short-run $\left(\beta_{0}\right)$ as well as the long-run $\left(\beta_{0} /\left(1-\sum_{i} \alpha_{i}\right)\right.$ or $\beta_{0}^{c}$ ) elasticities with respect to unemployment are commented.

As in some countries obvious outliers could be identified, the estimations are performed including a dummy variable correction for these outliers. 


\section{References}

Andrés, J., Bean, C.R., Blanchard, O.J., Jimeno, J.F., Malinvaud, E., Revenga, A., Saint-Paul, G., Snower, D.J., Solow, R., Taguas, D., Toharia, L. (1995): Spanish Unemployment: Is there a Solution?, CEPR, London.

Andrews, D.W.K. (1993): Tests for parameter instability and structural change with unknown change point, in: Econometrica, 6I(4), 82I-856.

Andrews, D.W.K., Ploberger, W. (1994): Optimal tests when a nuisance parameter is present only under the alternative, in: Econometrica, 62(6), I383-I4I4.

Arestis, P., Sawyer, M. (2005): Aggregate demand, conflict and capacity in the inflationary process, in: Cambridge Journal of Economics, 29(6), 959-974.

Ball, L. (1994): Credible disinflation with staggered price-setting, in: The American Economic Review, 84(I), 282-289.

Ball, L. (1997): Disinflation and the NAIRU, in: Romer, C., Romer, D. (eds.), Reducing Inflation: Motivation and Strategy, Chicago: University of Chicago Press, 167-185.

Ball, L. (1999): Aggregate demand and long-run unemployment, in: Brookings Papers on Economic Activity, 1999(2), 189-251.

Ball, L., Mankiw, N.G. (2002): The NAIRU in theory and practice, in: Journal of Economic Perspectives, I6(4), II5-I36.

Banerjee, A., Dolado, J., Mestre, R. (1998): Error-correction mechanism tests for cointegration in a single-equation framework, in: Journal of Time Series Analysis, I9(3), 267-283.

Bassanini, A., Duval, R. (2006): Employment patterns in OECD countries: Reassessing the role of policies and institutions, OECD Social, employment and migration working papers, No. 35 .

Bean, C.R. (1997): The role of demand-management policies in reducing unemployment, in: D. J. Snower, G. de la Dehesa (eds.), Unemployment Policy. Government Options for the Labour Market, CEPR, Cambridge: Cambridge University Press, 83-III.

Beyer, A., Farmer, R.E.A. (2002): Natural Rate doubts, ECB Working Paper, No. I2I.

Blanchard, O.J. (2007): A review of Richard Layard, Stephen Nickell, and Richard Jackmans unemployment: Macroeconomic performance and the labour market, in: Journal of Economic Literature, 45(2), 410-418.

Blanchard, O.J., Katz, L.F. (1997): What we know and what we do not know about the Natural Rate of unemployment, in: Journal of Economic Perspectives, II(I), 5I-72.

Blanchard, O.J., Summers, L.H. (1986): Hysteresis in unemployment, in: European Economic Review, 3I(I/2), 288-295.

Brown, R.L., Durbin, J., Evans, J.M. (1975): Techniques for testing the constancy of regression relationships over time, in: Journal of the Royal Statistical Society, Series B (Statistical Methodology) 37(2), I49-192.

Christiano, L.J., Eichenbaum, M., Evans, C. (200I): Nominal rigidities and the dynamic effects of a shock to monetary policy, NBER Working Paper, No. 8403. 
Denis, C., Grenouilleau, D., McMorrow, K., Röger, W. (2006): Calculating potential growth rates and output gaps - a revised production function approach, European Commission, Economic Papers, No. 247.

ECB (2006): Monthly Bulletin, August, European Central Bank, Franfurt/Main.

ECB (2007): Monthly Bulletin, June, European Central Bank, Franfurt/Main.

Eller, J.W., Gordon, R.J. (2003): Nesting the New Keynesian Phillips curve within the mainstream model of U.S. inflation dynamics, Konferenzbeitrag, CEPR Conference »The Phillips Curve revisited« in Berlin, 5.-7. Juni 2003.

Fabiani, S., Mestre, R. (200I): A system approach for measuring the Euro Area NAIRU, ECB Working Paper, No. 65.

Flaschel, P., Kauermann, G., Semmler, W. (2007): Testing wage and price Phillips curves for the United States, in: Metroeconomica, 58(4), 550-58I.

Franz, W. (2005): Will the (German) NAIRU please stand up?, in: German Economic Review, 6(2), I3I-I 53 .

Fuhrer, J.C., Moore, G.R. (I995): Inflation persistence, in: Quaterly Journal of Economics, IIO(I), I27-I59.

Galì, J., Gertler, M. (2007): Macroeconomic modeling for monetary policy evaluation, in: Journal of Economic perspectives, $2 \mathrm{I}(4), 25-45$.

Gordon, R.J. (198I): Inflation, flexible exchange rates, and the natural rate of unemployment, NBER Working Paper, No. 708.

Gordon, R.J. (1997): The time-varying NAIRU and its implications for economic policy, in: Journal of Economic Perspectives, II, II-32.

Grant, A.P., Thomas, L.B. (1999): Inflationary expectations and rationality revisited, in: Economic Letters, 62(3), 33I-338.

Haldane, A., Quah, D. (1999): UK phillips curves and monetary policy, in: Journal of Monetary Economics, 44(2), 259-278.

Hansen, B.E. (1997): Approximate asymptotic p-values for structural-change tests, in: Journal of Business \& Economic Statistics, I5(I), 60-67.

Hansen, B.E. (200I): The new econometrics of structural change: Dating breaks in U.S. labor productivity, in: The Journal of Economic Perspectives, I5(4), II7-I28.

Hein, E. (2006): Wage bargaining and monetary policy in a Kaleckian monetary distribution and growth model: Trying to make sense of the NAIRU, in: Intervention. European Journal of Economics and economic Policies, 3(2), 305-329.

Hein, E., Stockhammer, E. (2009): A Post Keynesian alternative to the New Consensus model, in: Fontana, G., Setterfield, M. (eds.), Macroeconomic Theory and Macroeconomic Pedagogy, Palgrave Macmillan, Basingstocke, chapter $\mathbf{I} 4$.

Iakova, D.M. (2007): Flattening of the Phillips curve: Implications for monetary policy, IMF Working Papers, No. $07 / 76$.

IMF (200I): Monetary and exchange rate policies of the Euro Area: Selected issues, Country report I/20I, International Monetary Fund.

IMF (2006): World Economic Outlook: Globalization and Inflation, Vol. April, International Monetary Fund, Washington D.C. 
Ireland, P. (1999): Does the time-consistency problem explain the behavior of inflation in the United States?, in: Journal of Monetary Economics, 44(2), 279-29I.

Johansen, S. (1995): Likelihood-Based Inference in Cointegrated Vector Autoregressive Models, Oxford University Press, Oxford.

Karanassou, M., Sala, H., Snower, D.J. (2003): Unemployment in the European Union: A dynamic reappraisal, in: Economic Modelling, 20(2), 237-273.

Katz, L.F., Krueger, A.B. (1999): The high-pressure U.S. labor market of the 1990s, Princeton University, Dpt. of Economics, Working Paper, No. 1999-05.

Laubach, T. (200I): Measuring the NAIRU: Evidence from seven economies, in: The Review of Economics and Statistics, 83(2), 218-23I.

Layard, R., Nickell, S., Jackman, R. (199I): Macroeconomic Performance and the Labour Market, Oxford University Press.

Logeay, C., Schreiber, S. (2006): Testing the effectiveness of the French work-sharing reform: A forecasting approach, in: Applied Economics, 38(I7), 2053-68.

Mankiw, N.G. (200I): The inexorable and mysterious tradeoff between inflation and unemployment, in: The Economic Journal, III(47I), C45-C6I.

Mankiw, N.G., Reis, R. (2002): Sticky information versus sticky prices: A proposal to replace the new Keynesian Phillips curve, in: The Quarterly Journal of Economics, II7(4), I295-I328.

McMorrow, K., Röger, W. (2002): Technical specification of the model used for the estimates, Internal note to economic trends, European Commission.

Modigliani, F., Fitoussi, J.P., Moro, B., Snower, D. et al. (1998): An economists' manifesto on unemployment in the European Union, in: Banca Nazionale di Lavoro Quarterly Review, SI, I-I9.

Nielsen, H.S. (2003): Essays on expectations, Shaker: Aachen.

OECD (1993): Italy, Economic surveys 1993-1994, OECD.

OECD (1994): The OECD Jobs Study: Facts, Analysis, Strategies, OECD, Paris.

OECD (2006): Employment Outlook, OECD, Paris.

Papademos, L. (2007): The effects of globalisation on inflation, liquidity and monetary policy, Speech at NBER-conference "international dimensions of monetary policy«, European Central Bank, $\mathrm{II}^{\text {th }}$ June.

Phelps, E.E. (1967): Phillips curve, expectations of inflation and optimal unemployment over time, in: Economica, 34, 254-28I.

Phillips, A.W. (1958): The relation between unemployment and the rate of change of money wage rates in the United Kingdom I86I-1957, in: Economica, 25, 283-299.

Pissarides, C.A. (2003): Unemployment in Britain: A European success story, CESifo Working Paper, No. 98I.

Richardson, P., Boone, L., Giorno, C., Meacci, M., Rae, D., Turner, D. (2000): The concept, policy use and measurement of structural unemployment: Estimating a time varying NAIRU across 2I OECD countries, OECD Working Paper, No. 250.

Roberts, J.M. (1995): New Keynesian economics and the Phillips curves, in: Journal of Money, Credit and Banking, 27(4), 975-984. 
Samuelson, P.A., Solow, R.M. (I960). Problem of archieving and maintainig a stable price level. Analytical aspects of anti-inflation policys, in: American Economic Review, Papers and Proceedings, 50, 177-I94.

Santomero, A.M., Seater, J.J. (1978). The inflation-unemployment trade-off: A critique of the literature, in: Journal of Economic Literature, I6(2), 499-544.

Sargan, J.D. (I964): Wages and prices in the UK: A study in econometric methodology, in: Hart, P.E., Mills, G., Whitaker, J. (eds.), Econometric analysis for national economic planning, London: Butterworths.

Schreiber, S., Wolters, J. (2005): The long-run Phillips curve revisited: Is the NAIRU framework data-consistent?, Goethe-Universität, Diskussionspapier, Frankfurt/Main.

Setterfield, M., Leblond, K. (2003). The Phillips curve and US macroeconomic performance during the I990's, in: International Review of Applied Economics, I7(4), 36I-376.

Solow, R.M. (2000): Unemployment in the United States and in Europe. A contrast and the reasons, in: ifo-Studien, 46(I), I-I2.

Staiger, D., Stock, J.H., Watson, M.W. (1997): The NAIRU, unemployment and monetary policy, in: Journal of Economic Perspectives, II, 33-49.

Staiger, D., Stock, J.H., Watson, M.W. (200I): Prices, wages and the U.S. NAIRU in the I990s, NBER Working Papers, No. 8320.

Stiglitz, J. (1997): Reflections on the natural rate hypothesis, in: Journal of Economic Perspectives, II, 3-IO.

Stockhammer, E. (2004): Explaining European unemployment: Testing the NAIRU hypothesis and a Keynesian approach, in: International Review of Applied Economics, I8(I), 3-23.

Taylor, J.B. (2000): Low inflation, pass-through, and the pricing power of firms, in: European Economic Review, 44(7), I389-I408.

Turner, D., Boone, L., Giorno, C., Meacci, M., Rae, D., Richardson, P. (200I): Estimating the structural rate of unemployment for the OECD countries, OECD Economic Studies 200I/II(33), I7I-2I6.

Wall, H.J., Zoëga, G. (2004): U.S. regional business cycles and the natural rate of unemployment, in: Review of the Federal Reserve Bank of St. Louis, 86(I), 23-32.

Walsh, C. (2005): Labor market search, sticky prices, and interest rate rules, in: Review of Economic Dynamics, 8(4), 829-849. 
